\title{
A Commentary on: Stringer J (1967) Operational research for "multi-organisations"* Opl Res Q., 18: 105-120
}

\author{
CJL Yewlett Department of City and Regional Planning, Cardiff University, UK
}

The wartime application by internationally distinguished scientists of 'scientific method' (in its widest sense) to matters of the most urgent current public importance is widely held to have established the credibility of UK Operational Research as an activity. However, the post-war focus of Operational Research in the UK moved away from broad public policy issues, to consider matters of more detailed industrial management ${ }^{1}$ (even though, ironically, continuing 'National Service' regulations meant that the UK's 'flag-ship' OR groups evolved in the nationalised Coal and Steel industries).

The involvement of the Tavistock Clinic in wartime issues (notably the selection of Officers) gave rise to a parallel post-war development. The Tavistock staff had developed a school of 'social psychiatry' outside mainstream contemporary medical opinion and, post-war, sought to extend their 'socio-psychological', and later 'socio-technical', insights to the wider society beyond clinical practice by the establishment of the Tavistock Institute: the 'Tavi',

In 1963, a convergence of interests occurred between the UK OR Society, and the Tavi. A number of UK OR practitioners had become increasingly concerned that OR, especially in academic circles, was becoming too focussed on the mathematical modelling of well-defined problems, at the expense of the more open-ended wartime spirit of scientific enquiry. They sought a connection with the social sciences, and Russ Ackoff's suggestion that the Tavi might provide a fruitful home led to the establishment of the Institute for Operational Research (IOR) within the Tavi framework.

Under its first Director, Neil Jessop, IOR launched a number of research projects: on communications in the building industry: on adaptation and change in hospitals; and on local government planning and policy making ${ }^{2,3}$. One of the first formally published outputs of this work was the present paper in 1967. John Stringer's paper addresses many of the issues of contemporary concern. Most significantly, it introduced the concept of the 'multi-organization', comprising a situation where "parts of several organizations ... are all involved in the achievement of a plan or of an end-result' (106), and went on to discuss the development of appropriate approaches for engaging with such entities. This was in stark contrast to the then current OR convention of 'advising the decision-maker', assumed to be a single individual, which, at least implicitly, underpinned much of the contemporary mathematical work.

The paper struck a distinct chord at the time, a fact recognised by the award of the OR Society's Bronze Medal for 1967. The concepts initially developed here have fed into a wide range of subsequent work, in IOR and elsewhere, on topics including Health ${ }^{4}$; Planning ${ }^{5}$, and Government (the latter in conjunction with the Civil Service Department ${ }^{6}$, Home Office, and Scottish Office amongst others), much of it undertaken under John Stringer's personal oversight as Director of IOR, following Neil Jessop's untimely death. The basic thrust of the paper remains as relevant today as when it was first written.

\section{References}

1 Rosenhead JR (1989) Operational Research at the Crossroads: Cecil Gordon and the Development of Post-War OR. J Opl Res Soc 40: 3-28.

2 Trist E and Murray H (eds.) (1993) Historical Overview, 1-34 in The social engagement of social science: a Tavistock anthology, Vol. 2, The socio-technical perspective, Pennsylvania University Press: Philadelphia.

3 Friend JK and Yewlett CJL (1974) Decision Making in the Local Provision of Public Services: a résume of Work in the Institute for Operational Research 1963-74. Delft, Netherlands: Planning Theoric Group. Technische Hogeschool, Delft.

4 Luck GM, Luckman J, Smith BW, and Stringer J (1971) Patients, hospitals and operational research. Tavistock Publications: London.

5 Friend JK and Jessop WN (1969) Local Government and Strategic Choice: an Operational Research Approach to the Processes of Public Planning. Tavistock Publications: London, Friend JK, Power JM, and Yewlett CJL (1974) Public Planning: The Intercorporate Dimension, Tavistock Publications London; Friend JK and Hickling DA (1997), 2nd Edn., Planning Under Pressure: The Strategic Choice Approach. Oxford: Pergamon Press.

6 Civil Service Department (1973) The dispersal of Government work from London. HMSO: London.

*An influential paper reprinted to commemorate the 50th Anniversary of the Journal. 